\title{
Education and Training of Special Collections Professionals, Librarians, and Archivists in Canada
}

I WOULD LIKE TO OPEN with two recent national events. The first concerns Library and Archives Canada/Bibliothèque et Archives Canada (LAC/BAC), a new institution created by federal legislation proclaimed on May 21, 2004, in a merger of the National Archives and the National Library. The National Archives was the older of the two entities. Established in 1872, it was the first cultural agency created after Confederation in 1867. An active collector from the outset, the Archives maintained offices in London and Paris, collected documentary art, photographs, and artifacts (including war trophies during the First World War), as well as books and newspapers. Although the records of governments, prime ministers, and other political figures constitute a major part of the holdings, the papers of organizations and individual Canadians also are collected and made available. The National Library was not established until 1953, even though its absence had been noted for almost a century. An outstanding collection of Canadiana has been developed there by legal deposit, aggressive acquisition policies, and transfers from other libraries such as the Library of Parliament. Its particular strengths are music, children's materials, and literary manuscripts. The common goal of the librarians and archivists in this new institution is to increase awareness and understanding of, and access to, Canada's documentary heritage. They are seeking partnerships with libraries, archives, and museums across Canada to develop services that are truly national, to shape innovative programs, and to provide unparalleled access to the collection. One initiative, which draws on the documentary art collection, is a Portrait Gallery to be housed in the former American Embassy.

Canada's other national library, the Bibliothèque nationale du Québec, opened its new Grande Bibliothèque in Montreal in May of this year. The BNQ, which was founded in 1967, incorporates the holdings of four earlier libraries established from the middle of the nineteenth century by the Sulpicians. Developed through legal deposit, retrospective acquisitions, and donations from individuals and other libraries, the collection is rich in Quebec and Canadian materials. Because Montreal was UNESCO's World Book Capital for 2005, the construction of a national library 
offering public library services in downtown Montreal was an exciting event, not least for the library profession and library educators.

There are only seven library schools in Canada, so I have surveyed them all, quite unscientifically, to prepare this paper. I contacted colleagues, checked Web sites, and consulted several special collections librarians. The theme of the 2005 RBMS Preconference suggested areas of particular interest to investigate. Reading from East to West, the schools are Dalhousie in Halifax; Université de Montréal; McGill, also in Montreal; University of Toronto; University of Western Ontario in London; University of Alberta in Edmonton; and University of British Columbia in Vancouver. Not surprisingly, there are more similarities than differences in their course offerings. No school has a program in special collections, although four have archives programs. Six of the seven schools offer some form of History of the Book. Western has a book industry course and McGill also offers a History of Libraries. Several of the schools list additional courses in publishing and reading. Materials courses such as Canadiana also would be useful for students building a special collection focus. Two schools offer courses in bibliography. McGill's course in descriptive bibliography treats the history, description, and care of rare books, as well as the function and administration of rare book collections. Toronto's course in analytical and historical bibliography (which I offered for many years) is hard-line descriptive bibliography; another popular course, Rare Books and Manuscripts, is taught each year. The Toronto faculty is also a partner in the university's graduate Collaborative Program in Book History and Print Culture, which I will discuss later.

All seven schools offer courses in digital libraries, digital collections, digital images, electronic text, etc. Each school also recognizes the importance of independent study and specialization with options such as reading courses, practicum placements, and theses. At Dalhousie, for example, students can complete a practicum in Special Collections and University Archives. Practicum topics at Toronto this past year included cataloguing at the Fisher Rare Book Library and evaluation of special collections in black history and local history in the public library system. Also this year I supervised, as a master's thesis, a descriptive bibliography of the Native writer Pauline Johnson. For librarians who want to change direction, several schools offer a graduate diploma for a one-year program, usually undertaken at least three years after the first professional degree. Book History is one of the specializations that has been successful at Toronto. To sum up, although there are no special collections programs in Canadian schools, a student can build the basics from regular courses and independent study. As I noted earlier, archives programs are more common, with a well-defined curriculum at four of the schools. The other three list a few courses, typically an introductory offering and Records Management. Only one institution, the School of Library, Archival and Information 
Studies at the University of British Columbia, offers a distinct degree-the master of archival studies (MAS) — established in 1981. UBC's MAS includes some twenty courses, a thesis option, and an internship. Three schools-Montréal, McGill, and Toronto-offer programs or streams within a common degree. A suite of required and elective archives courses identifies the specialization.

I would like to pause here to highlight two developments at different schools that seem to me to be indicators of trends linking libraries, archives, and museums. The University of British Columbia offers a First Nations Concentration in the MAS and MLIS degree programs. This specialization is designed to prepare information professionals to work in libraries and archives both within and outside Native communities and to deal with library, archival, and museum materials. The curriculum includes courses in education, anthropology, history, fine arts, law, and linguistics. At Toronto, the 2004-2010 Academic Plan of the Faculty of Information Studies (FIS) identifies as one of its priorities an alliance with the graduate program in museum studies, a two-year master's degree with a partially funded summer internship. Because libraries, archives, and museums deal with common questions in the acquisition, organization and classification, curating, presentation, and preservation of diverse cultural records, a proposal for consolidation has gained support within the university. Some of my colleagues are referring to this as the Year of the LAM, for libraries, archives, and museums.

Another of the acronyms common in our faculty is BHPC, the Collaborative Program in Book History and Print Culture, in which we play a major role. It is not a special collections program, but it offers a wonderful opportunity for specialization. Now entering its sixth year, BHPC was founded by six units: English and the Faculty of Information Studies (which agreed to share the teaching and administration), and French, Comparative Literature, Medieval Studies, and the History and Philosophy of Science and Technology. Academic reviews of the program have been positive and four additional units have joined: History, Fine Art, Italian, and Music. Enrolment is limited to fifteen candidates each year. Students from the Faculty of Information Studies form a majority in the master's cohort, while those in the PhD program are principally from the English Department. More than thirty FIS students have completed the program as part of their MISt degree and one of our first two $\mathrm{PhD}$ graduates was a FIS student, Leslie McGrath, curator of the Osborne Collection of Early Children’s Books, Toronto Public Library.

Yet despite its success, the program is limited. We offer only three courses: the core course taught jointly by FIS and English (which is required for all students), and two doctoral courses - a seminar and a practicum, which master's students may elect to take. The rest of a student's program is completed in the home department and from courses cross-listed with the collaborating units. Faculty from the other units partici- 
pate as guest lectures, members of thesis committees, and practicum supervisors. The program is centered at Massey College, which has an extensive book history collection and a pressroom. Across the campus at St. Michael's College, BHPC has inspired an undergraduate program in Book and Media Studies, which follows a similar pattern of core courses and cross-listings across a wide range of departments.

These academic programs, together with the public lecture series sponsored by the Toronto Centre for the Book, are intended for students and supported by our professional colleagues. Special collections librarians are regularly involved as instructors and as members of program and planning committees. Many are active on the national front as well as the local scene. Currently, the Bibliographical Society of Canada/La Société bibliographique du Canada has librarians in the offices of president, first and second vice-president, treasurer, and secretary. A project under consideration by the society is the revival of a summer course in analytical bibliography that was sponsored by the society and the National Library as a mini Rare Book School North in 1993 and 1995.

Over the past five years, the most visible project engaging special collections librarians and practically every special collection across the country has been the History of the Book in Canada/Histoire du livre et de l'imprimé au Canada. HBiC/HLIC is a bilingual project of national history being published in three volumes in both French and English editions. Volume One, Beginnings to 1840 was published in the autumn of 2004, Volume Two, 1840-1918 follows later this summer, and Volume Three, 1918-1980 is scheduled for 2006 or 2007 . The seven-person editorial team includes four librarians, including myself, three of whom are library educators. I am the project director and co-general editor. Of more than 170 other authors who have written for the three volumes, 49 are librarians and archivists and 4 are museum curators. Their topics include library history, printing technology, book illustration, bookselling, materials in Native languages, censorship, government printing, private presses, children's books, cookbooks, and Arctic shipboard printing. Quite simply, we could not have done this project without them.

I spoke earlier about consulting special collections librarians to find out what they look for in our graduates. The qualities and skills included enthusiasm for the materials, collegiality and flexibility, languages, subject specialization at the graduate level, cataloguing and digitization, public service orientation, fundraising ability, interest in working with faculty, and effective teaching. One colleague, a former student, summed it up as "a wider view." From my thirty years at library school (or forty if I count back to my own student days), these are the characteristics that distinguish many of the students attracted to special collections work. And this is what sustains us as educators and researchers in our common pursuits. 